\title{
Eski Arap Hicvinin Özgün Bir Edebî Tür Olarak Doğuşu ${ }^{1,2}$
}

\author{
Dr. Öğr. Üyesi Esat AYYILDIZ
}

Başvuru Tarihi: 22.01.2020

Kabul Tarihi: 20.12 .2020

Makale Türü: Araştırma Makalesi

\section{Öz}

Hiciv (hicâ') sanatı, Arap edebiyatının ana edebî tarzlarından biridir. Bu türün içerisinde, kusurlar, yenilgiler, budalaliklar, zaaflar, noksanliklar ve hatalar, tercihen kabilelerin, hiziplerin, ailelerin, bireylerin yahut bizzat toplumun kendisinin ıslah edilmesi amacıyla alaya alınmaktadır. Arapçadaki hicâ' sözcüğü, muhtemelen İbranicedeki h-g-h kökü ile eşasıllıdır. Hicâ"nın asli anlamı, "sessizce bir sedayı telaffuz etmek, mirıldanmak, büyülü sözler söylemek ve büyülemek" olabilir. Ayrıca bu sözcüğ̈̈n "tefekkür” manası da bulunmaktadır. Arap hicvinin kökeni, muhtemelen büyücülüğe dayanmaktadır. Söz konusu büyücülük, herhangi bir kabilenin veya bireyin itibarını zedelemesi umulan bir tür sihirli efsun yahut kâhinlere has bir lanetlemedir. İslam öncesindeki bir Arap yergicisi, kabilesinin kâhinidir. Arap edebiyatının ilk yergisel şiirleri, şeytanlarla ya da cinlerle iletişim kurduğu varsayılan kişilerce, düşmanların yok edilmesi amacıyla terennüm edilmiştir. Hicivcinin muazzam itibarı, büyücü olarak üstlendiği rolden kaynaklanmaktadır. Çünkü onun birincil vazifesi, efsunlu beyitler nazmetmektir. Bu şiirsel tür, erken dönem Arapları tarafindan, gerek müstakil ve kısa parçalar halinde gerekse çok temalı bir kasidenin tematik bir bölümü olarak geniş çapta işlenmiştir. Bu çalışmada eski Arap hicvinin doğuşu ve antik yergi gelenekleri ile ilişkisi incelenecektir.

Anahtar Kelimeler: Klasik Arap Edebiyatı, Klasik Arap Şiiri, Arap Hicvi, Büyücülük, Antik Mısır

Atıf: Ayyıldız, E. (2020). Eski Arap hicvinin özgün bir edebî tür olarak doğuşu. Anadolu Üniversitesi Sosyal Bilimler Dergisi, 20(4), 269-282.

\footnotetext{
${ }^{1} 2020$ yılı öncesi araştırma verileri kullanılmış olduğundan geriye dönük etik kurul izni gerekmemektedir.

${ }^{2}$ Bu çalışma, 2019 yllında Prof. Dr. Kemal TUZCU’nun danışmanlığında Ankara Üniversitesi Sosyal Bilimler Enstitüsünde hazırlanan "Klasik Arap Şiirinde Emevî Dönemine Kadar Hiciv" başlıklı tamamlanmış doktora tezinden üretilmiştir.

${ }^{3}$ Kafkas Üniversitesi, Fen Edebiyat Fakültesi, Doğu Dilleri ve Edebiyatları Bölümü, Arap Dili ve Edebiyatı Anabilim Dalı, esatayyildiz@hotmail.com, ORCID: 0000-0001-8067-7780
} 


\title{
The Rise of the Ancient Arabic Satire as an Original Literary Genre
}

\author{
Asst. Prof. Dr. Esat AYYILDIZ
}

Submitted by: 22.01 .2020

Accepted by: 20.12 .2020

Article Type: Research Article

\begin{abstract}
Satire (hidjâ') is one of the main genres of Arabic literature, in which vices, defeats, follies, foibles, shortcomings, and flaws are held up to ridicule, ideally with the intent of shaming tribes, sects, families, individuals, or society itself into improvement. The Arabic word hidjâ' may perhaps be cognate with the Hebrew root h-g-h. The original meaning of the root h-dj-w might have been "uttering a sound in low voice, murmuring, pronouncing incantations, and casting a spell"; it also has the meaning "meditation". It is likely that Arabic satire has its origin in sorcery; a magical incantation or fatidic curse that was supposed to tarnish the reputation of a tribe or an individual. The pre-Islamic Arabian satirist was the oracle (kâhin) of his clan. First satirical poems of Arabic literature were uttered by someone who maintained contacts with demons or djinnis, in order to destroy the enemies. The immense prestige of the satirist was deduced from his role as sorcerer, for his primary mission was to compose magical verses. This poetical genre has been widely cultivated by the early Arabs, either in separate and short pieces, or as the thematic element of a polythematic qasida. In this study, the rise of the ancient Arabic satire and its relation with ancient satirical traditions will be examined.
\end{abstract}

Keywords: Classical Arabic Literature, Classical Arabic Poetry, Arabic Satire, Sorcery, Ancient Egypt 


\section{Giriş}

Türkçedeki yergi veya hiciv teriminin Arap dilindeki karşıllğı, "el-hicâ"” (الهِجَاء) sözcüğüdür. Aynı kökten gelen ve aynı anlamı taşıyan "el-hecv" (الَهَجْو) kelimesinin, "el-hicâ"” sözcüğüne kıyasla, geniş bir kullanım alanı kazanamadığı görülmektedir. Edebiyattaki terminolojik niteliğini, İslam öncesinde kazandığı hususunda hiçbir şüphe bulunmayan "el-hicâ" terimi, sözlükte, "şiirle sövmek, alaya almak, dalga geçmek, tahkir etmek" manalarına gelmektedir (el-Fîrûzâbâdî, 2005, s.1345; Wehr, 1985, s.1341). Bünyesinde ağırlıklı olarak hakaret içerikli eleştiri ve aşağılama bulunduran, manzum veya mensur bütün edebî ürünler, hiciv kapsamında değerlendirilebilmektedir. Arap edebiyatında, hedef alınan kişi veya grupları, iğneleyen, karalayan, tehdit eden veya alaya alan bütün noktalar, bir şekilde hiciv sanatıyla doğrudan doğruya ilişkilidir. Her şeyden önce, mertlik veya muruvve kavramının, klasik Arap hicviyle direkt olarak alakalı olduğu vurgulanmalıdır. Çünkü klasik hicviyelerde, yerilen kişinin işe yaramaz olduğunun anlatılması, bireyin veya kabilenin, mertlik erdemini ihlal etmesi üzerinden gerekçelendirilmektedir. Hicvin başarısı, hicvedilen kişinin yetersizliğinin anlatılabilmesine ve yergicinin dehasına göre ölçülmektedir (Montgomery, 1986, s.5).

Erken dönem Arap edebiyatı, diğer kadim medeniyetlerin edebiyatlarına kıyasla, belki de fiziksel silahlarla en büyük benzerliği arz eden hicviyelerin üretimine sahne olmuştur. Bu yergilerde benimsenen metotlar, Arap gelenekleriyle mutlak bir uyum içerisindedir. İslam öncesinden itibaren, yergiciler karşılıklı söz düellolarına girişmekte, fikirlerini savunmakta, soylarıyla övünmekte, rakiplerinin neseplerine olabildiğince saldırmaktadır. Yer yer yükselebilen tansiyona rağmen, bu hicviyeler çoğu zaman askerî nezaket kurallarına benzeyen bir mutabakat çerçevesinde nazmedilmektedir. İftira ve sövücülüğe dalan bazı hicviyelerin mevcudiyeti, bu sportmenliğin gölgelenmesi için yeterli değildir. Barışın korunması açısından talihsiz bir durum olan uzun soluklu kabile husumetleri, Arap hicvinin bu bağlamda gelişmesinde muazzam bir etkiye sahiptir (ed-Dehhân, , t.y., s.5). Görünüşe göre, Arap şairleri, icra ettikleri yergicilik faaliyetlerinin, büyük ölçüde askeriyenin desteklenmesine hizmet ettiğinin bilincindedir. Klasik Dönemin şairleri, kendilerini kabileleri için savaşan atlılara denk tutmakta, hatta onlardan daha yararlı olduklarını düşünmektedir. Öyle ki, yergicilik faaliyetlerindeki yararlılıklarını anlatmak isteyen şairlerin, kendilerinden "sonu gelmez savaşın efendisi” "midrehu'l-ḥarbil-'avân” (مِدْرَه الْحَرْب الْعَوَانِ) diye bahsettikleri görülmektedir (İbn Zâkûr, 2013, c.1, s.563).

Hiciv şairlerinin, genellikle içgüdülerinin kontrolü altında hareket ettiğini söylemek mümkündür. Yergicilerin çoğu zaman ilhamlarını, doğrudan doğruya tabiatın kendisinden veya çevrelerinde gözlemledikleri davranış biçimlerinden aldıkları ise büyük bir sır değildir. Tabiri caizse, yaşamlarını tamamen vahşi doğa kanunlarının tahakkümü altında idame ettirmeye çalışan erken dönem yergicilerinin hicivcilik tekniklerine bakılması, bu durumun en bariz yansımalarının gözlemlenebilmesi için fazlasıyla yeterli olacaktır. Nitekim bilhassa erken dönem hicivcilerinin kasidelerinde, tehdit, gözdağı ve aşağılama gibi en ilkel tepkilerin kolaylıkla gözlemlenebileceği sayısız örneğe rastlanmaktadır. Bu bağlamdaki kabilecilik taassubu da, gruplar arasındaki çekişmelerin etkisiyle, tabii eğilimlerin neticesinde ortaya çıkmaktadır. Elbette klasik Arap hicvinin en büyük destekçisi olan kabilecilik bilincinin, içgüdüsel kökenlerinin bulunduğu ve bu mefhumun direkt olarak kitle psikolojisi ile ilişkili olduğu açıktır. İnsanlardaki kitle psikolojisinin, daha büyük grupları daha küçük gruplara saldırmaya yahut onların sahip olduklarını gasp etmeye itebileceği bilinmektedir (Russell, 1959, s.57).

$\mathrm{Bu}$ durumda öyle görünmektedir ki, şair hiciv söylemek için lazım gelen motivasyonu, gerekli koşullar sağlandığında, dolaysız olarak toplumda şahit olup tecrübe ettiği çekişmelerden ve doğrudan parçası olduğu insan cemiyetinden almaktadır. Söylediği hicivlerle düşman grubuna zarar vermesi neticesinde, hem kendi grubu içerisinde statüsünü yükseltmekte hem de rakipleri karşısında güçlü bir otorite figürü haline gelmektedir. Dolayısıyla hiciv şiirlerinin ortaya çıkmasındaki en önemli etkenlerin, doğal içgüdüler ve kitlesel eğilimler olduğu açıktır. Şairler hicviyelerini, kendi hayat tecrübeleri, beğenileri, korkuları, tercihleri, 
çekingenlikleri ve pek çok insanî duygu ile dokumuşlardır. Bu nedenle psikolojik açıdan hicvin, hem bireysel hem de kolektif etkenleri olduğunu özellikle belirtmek gerekmektedir.

"Hicâ"” sözcüğünün etimolojik arka planı, en az Arap yergisinin gizemli kökeni kadar heyecan vericidir. İbn Manẓûr (ö. 711/1311)'un Lisânu'l-'Arab adlı ansiklopedik sözlüğünde, bu terimin, "hecâ" هَجَ fiilinin mastarı olduğu belirtilmektedir. Muḍ̂ari hali "yehcû" (يَجْجُ) olan eylemin diğer mastarları, "hecv" (هَجْو) ve "tehcâ"” (تَهْجَاء) kelimeleridir. Bu kökün yaygın kullanımının, "şiirle küfretmek" manasını ihtiva ettiği ve methiyenin (medh) zıddı olduğu ifade edilmektedir. "Tehâcâ" (تَهَجَى ) fiili, kişilerin birbirini hicvetmesi manasına

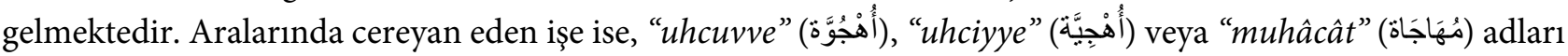
verilmektedir (İbn Manzû̂r, t.y., c.15, s.353). Kendisini hicveden birisine yönelik, Hz. Peygamberin ettiği bir beddua, İbn Manẓur gibi sözlükçüler tarafından, hiciv teriminin kullanımına kanıt olarak sunulmaktadır (İbn

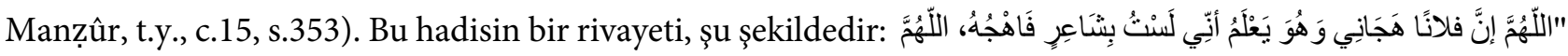
"Allah’ım, Filan kişi beni hicvetti. Benim şair olmadığımı biliyor. Sen de (onun) hicv(ine karşılık ver)! Allah'ım, beni hicvettiğinin sayısınca ona lanet et!” (er-Râzî, 1401/1981, c.2, s.77)

İbrani dilinde, "kısık sesle bir şeyler söylemek, mirlldanmak" manalarına gelen, "h-g-h" (הגה) kökü ile Arapçadaki "hecv" (هَجْو) kökü, etimolojik açıdan, eşasıllıdır (König, 1910, s.75; Bensew, 1862, c.1, s.123). Aynı kök, Süryanicede, "tefekkür etmek" manasındaki "hgo" kelimesiyle karşımıza çıkmaktadır (Smith, 1998, s.99; Atto, 1990, s.52). Bu sözlükbirimi, esasen Arami, Tigre ve Ugaritik dillerinde de bulunan, Semitik " $h-g-y$ " köküne dayanmaktadır. Söz konusu kelime, benzer şekilde tüm bu dillerde, "konuşmak, okumak, saymak ve mırıldanmak" manalarını ihtiva etmektedir. "Okumak" ve "düşünmek" arasındaki benzerlik, Talmud, Midraş ve Targum metinlerindeki " $h-g-y$ ” kökünde de karşımıza çıkmaktadır. Keza Kumran metinlerinde de görülen benzer manalar, oldukça ilginç şekilde, sözleri yozlaşmış insanların telaffuzları ile ilişkilendirilmektedir (Stordalen, 2013, s.22).

\section{Kadim Arap Hicvinin Antik Dünyadaki Yergi Gelenekleriyle ilişkisi}

Arap edebiyatındaki hicivcilik geleneği, antik dünyanın yergileriyle mukayese edildiğinde, Araplar arasındaki hicivcilik anlayışının, büyük ölçüde özgün bir kültürel aktarıma dayandığı gözlemlenmektedir. Dünya edebiyatının ilk yergileri, muhtemelen bugünkü Arap dünyasının sınırları içinde kalan, eski yerleşim birimlerinde söylenmiştir. Ancak hicvin başlangıcının tarih öncesine uzanması dolayısıyla, sürecin ilk örneklerinin mahiyeti veya ilk yergicilerin kim olduğu, aralanması güç bir sır perdesinin ardına gizlenmiş durumdadır. Eski Mısır’ın, Mezopotamya'nın ve ilk Sâmî yerleşkelerinin hicivcilik faaliyetleri hakkında, ne yazık ki tatmin edici verilere sahip değiliz. Bilindiği üzere, geçen zamanın ve yıkıcı savaşların tahripkâr gücüne dayanamayan dikili taşlar, kil tabletler ve papirüsler, büyük ölçüde kayıp tarihin tozuna bulanmıştır. Dolayısıyla zaferlerinin ardından düşmanlarını yeren kahramanların hicviyeleri veya din karşıtlarına beddua formunda lanetler okuyan kâhinlerin büyüsel yergileri, çoğu kez yok olmaktan kurtulamamıştır (ed-Dehhân, t.y., s. 7). Yine de bu coğrafyanın en eski hiciv örneklerinin mahiyeti hakkında tutarlı fikirler edinmemize olanak sağlayacak bir takım temel verilere ulaşılması hususunda büsbütün karamsarlığa düşülmesi de doğru olmayacaktır. Nitekim yergisel anlatımlar içeren az miktardaki kayıt, günümüze kadar ulaşmayı başarmıştır.

Eski Mısır'da hicivcilik faaliyetleriyle uğraşıldığı bilinmektedir. Belirli meslek dallarını olumsuz şekilde ele alan, "Meslekler Hicvi" yahut "Dua-Kheti Öğretisi" (Die Lehre des Cheti) adındaki metin, bunun en güzel örneklerinden biridir. Geçmişi muhtemelen M.Ö. 2150-1750 yıllarına kadar uzanan bu Eski Mısır anlatısının (Wilson, 1992, s.432), dolaylı yollardan Arap hicvine de ilham vermiş olması, zayıf bir ihtimal olsa da mümkündür. Nitekim kadim kültürlerin hicivcilik öğretilerinin, Sâmî bilginler arasında bir şekilde aktarılageldiği bilinmektedir. Örneğin; M.Ö. 2. yüzyılın başlarında, Yahudi âlimi Ben Sira’nın, Eski Mısır'daki 
bu yergiye Sirak kitabında başvurduğu gözlemlenmektedir (Rollston, 2001, s.131-139). Dolayısıyla Arapların Antik Mısır hicivciliği ile gerçekten de bir bağlantısı varsa, bu iletişim ağı yalnızca kadim öğretilerin Arabistan'daki taşıyıcılığını üstlenen İbranî bilginlerinin aracılı̆̆ıyla kurulmuş olabilir. İslam öncesinde ve İslam'ın ilk yıllarında Yahudi bilgeliği, Arap kabileleri arasında gereğince takdir edildiğinden, bu iletişim ağının bir şekilde kurulmuş olması mümkündür.

Eski Arapların, belirli meslek gruplarını hicvetmeye meraklı olduğu, sağlam verilerle kanıtlanabilmektedir (elA'şâ, t.y., s.231; Huseyn, t.y., s.72). Ancak Arapların bu yergilerde kadim kültürlerden ne dereceye kadar etkilendiğinin sağlam bir yargıya bağlanması söz konusu olduğunda, aynı kesinlikten söz etmek mümkün değildir. Antik Mısır'daki Meslekler Hicvi ile erken dönem Arap yergilerinden birinin kıyaslanması, durumun bir dereceye kadar somutluk kazanması açısından yararlı olacaktır. Örneğin; söz konusu antik metinde, ziraatla uğraşmayı angarya olarak gören Mısır seçkinleri, tarım işçiliğini şu şekilde yergiselleştirmektedir:
"Tarla işçisi sonsuza dek feryat eder. Sesi kuzgununkinden bile daha yüksektir. Parmakları aşırı ufunetle ülser olmuştur. Delta çalışmasında bitap düşmüştür; paçavralar içindedir. Aslanlar arasında iyidir; ama tecrübesi acılıdır. Sonra angarya üçe katlanır. Eğer oradaki bataklıklardan dönerse, angarya onu mahvettiği için, evine bitap düşmüşşsekilde ulaşır (Simpson, 2003, s.434).”

Tarım işçiliğinin, Arap şiirinde nasıl yergiselleştirildiğine baktığımızda, Bedevî bakış açısının muazzam bir baskınlık kazandığı gözlemlenmektedir. Örneğin; Meymûn b. Kays el-A'şâ (ö.7/629?), bedevi adetleri gereğince, deve sürülerine sahip olmakla övünürken, ziraatla uğraştıkları gerekçesiyle İyâd kabilesini hicvetmektedir:

"(Sen bizi İyâd gibi çiftçilik ehli mi sandın?) Tikrit'i yurt edinip (tarlaya ektiği tohum) tanesinin hasat edilmesini gözleyen İyâd gibi (ziraatla uğraşacak kişiler) değiliz biz.

Onlar öyle bir kabiledir ki, (bitlendiklerinden) oğulları bit tedavisiyle uğraşır; zincirlerle sağlamlaştırılmış, üzerlerine kapı(lar) örtülmüş̧ür. (Onlar bizim gibi babayiğit bedeviler değildir.)

el-İlah, bizim aşımızı malımızın içinden (yani deve sürülerimizden) vermiştir. Bize, garantisini sağladiğı, asla tükenmeyecek bir rızık (vermiştir) (el-A'şâ, t.y., s.231).”

Görüldüğü üzere, Eski Mısırlılarla Arapların, hiciv hususunda bazı ortak fikir nüvelerine sahip olduğu bir gerçektir. Ancak bu fikirlerin işlenişinde, doğal olarak büyük kültür farklılıkların bulunduğu gözlemlenmektedir. Arap hicvine ilham vermesi ihtimal dâhilinde olan tek medeniyet, Mısır değildir. Nitekim pek çok konuda ilkleri gerçekleştirmesine alışık olduğumuz Sümer medeniyeti, çevrelerindeki göçebe topluluklara, hiciv sanatı hususunda da ışık tutmuş olabilir. Sümerlilerin kaleme aldığı antik yergilerdeki anlatım tarzları dikkate alındığında, söz konusu edebî ürünlerle Arap hicviyelerinin arasında, büyük benzerliklerin gözlemlenebileceği görülmektedir. Örneğin; bu metinlerde, Sâmî halklarından olan Amurruların (Mar.tu) barbarlıkları, eski Arap hicviyelerinde olduğu gibi, açık ifadelerle anlatılmaktadır. Burada, bazı Arap yergicilerinin benimsemiş olduğu anlatım tarzlarına benzer şekilde (el-Ḳayrevânî, 1401/1981, c.1, s.123), hedef alınan kişinin yerilmesi, onun övülecek değerlerden soyutlanması üzerinden gerçekleştirilmektedir. Diğer bir deyişle, eleştirmenler tarafından tercih edilen Arap hicviyelerinde olduğu gibi, hedef alınan kişinin yerilmesi, olumsuzluk ögesi (negative particle)'nin yardımına başvurularak dolaylı bir anlatım üzerinden gerçekleştirilmektedir:

"Mar.tu, tahılı bilmez... Ne ev bilir ne kent... Mar.tu, yer mantarı eșer... Dizlerini (tarım yapmak için) bükmez; çĭg et yer. Ömrü boyunca hiç evi olmaz. Ölümünün ardından gömülmez (Bryces, 2014, s.17).” 
Kolaylıkla fark edileceği üzere, buradaki anlatım tarzları, erken dönem Arap hicviyelerini fazlasıyla anımsatmaktadır. Öte yandan söz konusu metnin yergiselliğinin, Arap hicvine nakledildiği varsayılırsa, hipotetik naklin eksen kaymasına uğradığı gözlemlenecektir. Nitekim Sümerlilerin yerdiği grup, Sâmî halklarından olan göçebe bir topluluktur. Hal böyle olunca, yerilen tarafın hicvedildiği noktalar, Bedevî Arapların yaşam biçimleriyle aynıdır. Dolayısıyla Araplar, yerleşik toplumların göçebe toplumlara yönelttiği yergileri kendi kültürlerine uyarlayarak yergiselliklerini yeniden ayarlamış olmalıdır. Örneğin; Sümer yergilerinde tarım yapmamak hicvediliyorken, Araplar tarafından ziraatla uğraşmak hicvedilmektedir (el-A 'şâ,, t.y., s.231). Sümer hicivlerinde tahıl ürünleriyle beslenmemek yerilirken, Arap hicvinde buğday veya Irak hurması gibi tarımsal ürünler hicviyelere konu edilmektedir (Geyer, 1892, s.7, 36-37).

$\mathrm{Bu}$ antik metinde, belirli yiyeceklerin yenilmesinin yerilecek bir özellik olarak kabul edilmesi gerektiği fikrinin, Sümerliler tarafından ortaya atıldığı gözlemlenmektedir. Arap şairlerin, bu öncü fikirleri büyük ölçüde benimseyerek hicviyelerinde tatbik etmeye başladığı aşikârdır. Elbette Arap hicvinde yerilen yiyeceklerin hangisi olması gerektiği belirlenirken, toplumun kendi kültürel değerleri esas alınmaktadır. Örneğin; Arap yergilerinde sehîne veya hurma süprüntüsü gibi belirli yiyecekleri yiyenler hicvedilmektedir (İbn 'Abdi'l-Berr, 1412/1992, c.3, s.1325; İbn Hişâm, 1375/1955, c.2, s.212-213). Çiğ et yenmesi, Sümer'de olduğu gibi, Arap kabileleri arasında da hicvedilmektedir. Zuheyr b. Ebî Sulmâ (ö. H.Ö.13/609) gibi İslam öncesinin meşhur yergicileri, çiğ et yenmesini hak yenmesinin simgesi olarak yergiselleştirmektedir (Zuheyr b. Ebî Sulmâ, 1426/2005, s.9-15; Kur’an-1 Kerim, 2018, Hucurât 49/12). Gıda maddelerinin verdiği haz, damak zevkine göre değişiklik arz ettiğinden, Araplar arasında bu hususta sabit yargıların benimsenememiş olması şaşırtıcı değildir.

Sümer'in hicivcilik geleneklerinin, Amurrular gibi bölgenin göçebe Sâmî halklarının aracilığıyla, Arap yergiciliğine dolaylı şekilde aktarılmış olabileceğine dair bazı dilbilimsel savlar ortaya atmak mümkündür. Bunun kanıtlanması için etimolojiye ve biçimsel incelemeye başvurduğumuzda, ikna edici bazı sonuçlara ulaşılabilir. Sümerliler tarafından, yaklaşık M.Ö. 2000 yıllarında ortaya konduğu düşünülen yergisel içerikli edebî bir deneme, bu açıdan hayati öneme sahiptir. Söz konusu metin, Sümer ülkesindeki günlük eğitimöğretim yaşantısını ironik bir dille ele almaktadır. Eğitimdeki aksaklıkları, döneme özgü yergisel bir üslupla aktaran yazı, muhtemelen tarihin kayıtlı ilk "yağcılığını" da konu edinmektedir. Metnin anlatım tarzı, Arap yergilerine fazla benzemese de düzensiz uyakların kullanılması, Arap edebiyatındaki yergisel kâhin secilerini belirli bir ölçüye kadar anımsatmaktadır. Örneğin; metnin girişinin transliterasyonu şu şekildedir (Kramer, 1949, s.199-215; Kramer, 2002, s.28-31):

“dumu-é-dub-ba-a u-ul-la-la-àm me-šè ì-du-dè-en é-dub-ba-a-šè ì-du-dè-en"

$\mathrm{Bu}$ yergide kullanılan bazı sözcüklerin, dolaylı yollardan Arapçaya ödünçlenmiş olması, iki edebiyatın arasındaki kadim ilişkinin etimolojik kanıtlarındandır. Örneğin; Sümercede "okul" manasına gelen "é-dub-ba" (tablet-evi) kelimesi (Kramer, 1949, s.199-215), Arap dilindeki "edebiyat" "edeb" (أََب) terimine ilham vermiş olmalıdır. Yazıcılıkla ilgili başka kelimelerin de Sümerceden ilham alınmış olması muhtemeldir. Diller arasındaki bu etkileşim göz önüne alındığında, bahsi geçen Sümerce sözlükbiriminin pek çok dile ödünçlenmiş olması, eski Arapların Sümer yergiciliğinden bir şekilde etkilendiğinin kanıtlanabilmesi açısından, son derece önemli bir etimolojik delil mahiyeti kazanmaktadır (Ball, 1913, s.59; Nork, 1842, s.169). Zira söz konusu Sümer yergisi, çetin yazı çalışmalarıyla uğraşmak mecburiyetinde kalan bir öğrenciyi merkezine almaktadır. Dolayısıyla çivi yazısının mucidi olan Sümerlilerin önderliğinde, yazı sanatını öğrenen yabancı milletlerin, bu tarzdaki yergisel metinleri incelememiş olduğunu düşünmek mümkün değildir. Bu yüzden bölgenin kadim halklarının hamiliği vasıtasıyla, hicivciliğe dair ilk fikir nüvelerinin Arap kabilelerine kadar ulaştırılmış 
olduğunu varsaymak yanlış olmayacaktır. Elbette binlerce yıllık bu yergi mirası, Arap kabilelerine ulaştırılana kadar, pek çok dilin ve pek çok neslin râvîliğinden süzülerek muazzam değişimlere uğramış olmalıdır.

Muhtemelen Eski Babil, Arap hicvine kaynak teşkil eden önemli kültür duraklarından biridir. Babil'in yergicilik faaliyetlerinin, Arap hicvine yaptığı varsayımsal etki, kesinlikle yabana atılmamalıdır. Nitekim eski Arap yergisinin büyüsel arka planı, sihre meraklı olan Babil halkının dinsel geleneklerinden çok şey kazanmış olmalıdır. Çünkü Babil’in dinî seremonilerinde, hicviyelere benzerlik arz eden söylemlerin kullanıldığ1 bilinmektedir (ed-Dehhân, t.y., s.7). Yine de Arap hicvinin büyüsel lanetlemelerle ilişsisinin, hangi medeniyetlerin yönlendirmeleriyle şekillendiğinin tespit edilebilmesi mümkün görünmemektedir. Antik Mısır'da da mezar soyguncularına karşı bir takım şiirsel lanetlemelerin kullanıldığı malumdur. Hindistan ve Çin gibi diğer kadim kültürlerde, barışı bozan, kötülüğe yol açan ve putlara saygısızlık eden kimselere karşı hiciv şiirleri söylenmektedir (ed-Dehhân, t.y., s.7). Ancak Arap yergisinin, Sâmî yurdunun dışındaki hiciv geleneklerinden etkilenmiş olması pek mümkün değildir.

\section{Kadim Arap Hicvinin Sihir Sanatıyla İlişkisi}

Kadim Arap hicvinin en gizemli yönlerinden biri, bu sanatın bir şekilde büyücülükle ilişkili olduğunu düşünmemize neden olan, son derece ikna edici bazı göstergelerin bulunmasıdır. Araplar arasındaki hicivcilik anlayışının, İslam öncesinden bu yana, bir şekilde lanetlemelerle bağlantılı olarak gelişim gösterdiği gözlemlenmektedir. Yergicilerin, kabilelerinin düşmanlarına veya kendi kişisel rakiplerine karşı söyledikleri ilenme sözleri, esasen klasik yergi kasidelerindeki baskın ögelerden biri değildir. Ancak beddua ifadeleri, erken dönemlerden itibaren, o veya bu şekilde kullanılagelmektedir. Siḥr (veya daha dar anlamda ta'vîzz (تَّو

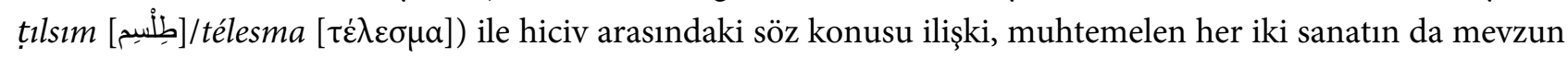
söylemlerin aracılığıyla icra ediliyor olmasından kaynaklanmaktadır (Mevsû́atu'ş-Şurûk, 1994, c.1, s.306; Willmet, 1784, s.464). İslam öncesi Araplarının dinsel hayatına dair elimizde bulunan veriler göz önüne alındığında, insanların yaşamı üzerinde, dinin fazla etkisi olmadığı kolaylıkla saptanabilmektedir. Ancak eski Arapların büyücülük hususundaki batıl inançlarının ne kadar derine uzandığının çözümlenebilmesi, bu kadar kolay olmayacaktır. Çünkü teorik ve entelektüel bir sistemden uzak olan bu dinsel gelenekler, daha çok büyüsel mahiyetteki uygulamalarla ilişkilidir (Figueroa, 1975, s.92).

Kâhinler ile iletişim kurduğuna inanılan, tâbi“ (takipçi/yoldaş), șâhịib (dost), mevlâ (arkadaş), velî (yakın dost), ra’̂̀/ri'̂̀ (kâhin) yahut şeyțânu'l-kâhin (kâhin şeytanı) gibi tanımlamalarla adlandırılan, kötü ruhlu, doğaüstü varlıklar, İslam öncesinin dinsel geleneklerinde oldukça önemli bir yer işgal etmektedir. Keza aynı durum, şairler için de geçerli olduğundan, bu varlıklar şeyâțînu'ş-şu'erâ' (şairlerin şeytanları) olarak da anılmaktadır (et-Tuncî, 1419/1999, c.2, s.576-577; Apak, 2015, s.59). Anlaşılacağı üzere, kâhin şeytanları ile şair şeytanları arasında son derece yakın bir ilişki söz konusudur (van Vloten, 1893, s.186). Özellikle erken dönem Arap yergicileri ile ilham cinleri arasındaki ilişkiye dair rivayetlerin günümüze kadar ulaşabilmiş olması, konunun

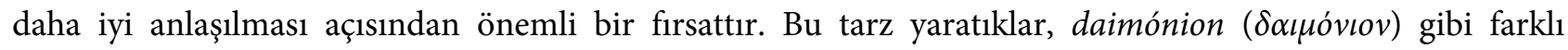
adlandırmalarla, pek çok mitolojide yer almasına rağmen, cinlerin veya şeytanların hicivcilikle ilişkilendirilmesi, daha ziyade Arap edebiyatına özgü bir yaklaşımdır. Özellikle İslam öncesindeki standartlaşma aşamasının hemen öncesinde, cinlerin hicivcilikle bağdaştırılmasının, çok daha baskın bir karaktere sahip olduğunu düşünmek mümkündür. Yergicilerin şeytanlardan kuvvet aldığı hususundaki intibaın canlı tutulması yönündeki eğilim, muhtemelen edebiyatın kalıplaşmaya başlamasıyla birlikte büyük ölçüde zayıflamıştır. Ancak cinlerin hicivcileri desteklediğine dair göz boyayıcı hurafeler, hem İslam öncesinde hem de İslam sonrasında, belirli şairlerin ekseninde dilden dile dolaşmaya devam edecektir. Örneğin; İslam öncesi şairlerinden 'Abîd b. el-Abraș (ö. 555 [?])'ın, bir takım doğaüstü güçlerden yardım almasının akabinde, 
daha önce hiç şairlik deneyimi olmamasına rağmen, onurunu zedeleyen kişileri hicvedebilecek kudrete eriştiği anlatılmaktadır (Goldziher, 1891, s.685).

Oryantalizm çalışmaları kapsamında, eski Arap hicvine dair ilk ciddi araştırmayı yapan kişi, Yahudi asıllı Macar müsteşrik Ignaz Goldziher (ö.1921)'dir. Onun Abhandlungen zur arabischen Philologie adlı eserinde yer alan "Ueber die Vorgeschichte der Hiǵĝ'-Poesie" ismindeki bölüm, erken dönem Arap hicvinin büyüsel kökenine dair çok önemli fikirler ihtiva etmektedir. Goldziher'e göre, hicvin başlangıcı, direkt olarak büyücülükle veya lanetlemelerle ilişkilidir. Ruhsal olgunluğa sahip kimseler tarafından belirli şartların sağlanmasıyla ve doğaüstü güçlerin yardımıyla söylenen hicviyelerden beklenen, hedef alınan kişi veya grupların üzerinde olumsuz etkiler bırakabilmesidir (Goldziher, 1896, c.1, s.27). Şiirlerdeki ritmik ahenk, düşmanlarını lanetlemek isteyen büyücülerin başvurduğu duaları (ed'iye) ve ilahileri (terâtîl) andırmaktadır. Hatta Hz. Peygamberin hem büyücülükle hem de şairlikle suçlanması bu yüzdendir (Mevsû'atu'ş-Şurûḳ, 1994, c.1, s.306; Ḍaf, t.y., c.1, s.196). Hicviyeler muhtemelen ilk olarak sec' ve recez formlarında icra edilmiş, zamanla olgunlaşarak klasik kaside biçimindeki nihai haline evrilmiştir. İslam öncesinde kâhinlerin yoğun şekilde $\sec ^{`}$ kullandığı bilinmektedir (Jacob, 1897, s.178).

Hicivle büyücülüğün ortak noktaları, yalnızca ritmik anlatım biçimlerinin benzerliğiyle sınırlı değildir. Karalama ve lanetleme işlemlerinin gerçekleştirildiği esnada, hem hicivcilerin hem de büyücülerin, bazı özel ritüellere başvurduğu gözlemlenmektedir. Tahmin edileceği üzere, sihirbazlar sanatlarını icra ederken belirli düzenekler vasıtasıyla, etrafındaki insanları etkilemeye çalışmaktadır. Bu süreçte kâhinlerin tütsü yaktığı, maske taktığı ve özel kıyafetler giydiği bilinmektedir. Büyücünün, insanları şeytanlarla iletişim kurduğuna veya ruh göçü yaptığına inandırabilmesi, bu gösterinin en can alıcı kısmıdır. Bu ritüellerde cinlere düştüğü varsayılan görev, büyücüye düşmanlarına zarar vermesinde yardımcı olmaktır. Benzer şekilde, bazı yergiciler hiciv söylemeden önce, rahatsız edici bir görünüme bürünmeye çalışmaktadır. Hicivciler bu süreçte, korkutucu bir imaj oluşturabilmek adına, saçlarını belirli şekillerde tıraşlamakta, başlarının bir kısmını yağlamakta, peştamallarını gevşetmekte ve yalnızca tek ayaklarına ayakkabı giymektedir (Mevsû‘atu'ş-Şurûk, 1994, c.1, s.306; Şemseddin, 1423/2002, c.5, s.65-67). Şairlerin bu uygulamalarının, büyücülük geleneklerinin bir yansıması olduğu aşikârdır. Çünkü yalnızca tek bir ayağa ayakkabı giyilmesinin, Hz. Peygamber tarafından

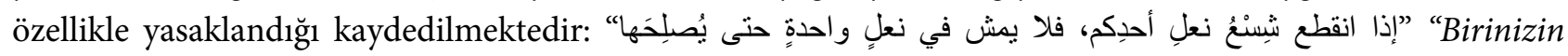
ayakkabısının kayışı koparsa, onu tamir edene kadar tek ayakkabıyla yürümesin (Yakup b. İshak, 1419/1998, c.5, s.266).” Hz. Muhammed'in tek ayakkabıyla yürünmesini yasaklamasının nedeni, muhtemelen denge probleminden ziyade, bu işlemin büyücülükle ilişkilendirilmesinden kaynaklanmaktadır.

Goldziher, Balak'ın Balam'dan söylemesini istediği lanet sözlerini, ilk hiciv örneği olarak değerlendirmektedir. Hiciv sanatının lanetlemelerle olan ilişkisinin daha iyi anlaşılmasına katkı sağlayacağını düşündüğü bu kaydın, Arap hicvinin kökenine sşı tutabileceği kanaatindedir (Goldziher, 1896, c.1, s.42). Bu kıssa hakkında Ahd-i Atîk’te geçen pasaj şu şekildedir:
"Şimdi gel, benim için bu kavme lânet et! Çünkü benim için çok kuvvetliler. Belki muzaffer olurum da onu vururuz ve onu memleketten kovarım. Zira biliyorum ki, senin kutlu kıldığın mübarek olur; lanet ettiğinse melun olur (The Holy Bible, 2011, Numbers, 22:6, s.83).”

İlerleyen yıllarda Clément Huart (ö. 1926), Golziher’in bu tezini benimseyecektir (Huart, 1903, s.8). Böylelikle Arap hicvinin ilk örneklerinin, düşmana karşı söylenen lanetlemelerden ibaret olduğu yönündeki değerlendirmeler, saygın otoriteler arasında belirli bir tanınırlık seviyesine ulaşabilmiştir. Hâlbuki Kitâb-1 Mukaddes'teki lanetlemelerin, Arap hicvinin kökenini temsil edebileceği hususundaki bu iddialara kuşkuyla yaklaşmak gerekir. Nitekim Arap hicvinin mevcut prototiplerine benzerlik arz eden en eski kayıtlar, Balak ve Balam'ın yaşadığı varsayılan zaman diliminin çok öncesinde kayıt tutmaya başlayan Sümer gibi antik 
medeniyetlerin çivi yazıtlarının arasında bulunmaktadır (Bryces, 2014, s.17). Öte yandan Arapların hicivcilik geleneklerinin büyücülükle harmanlanmış olmasında, Yahudi adetlerinin rolü muhtemelen çok büyüktür.

İlerleyen yıllarda Fransız oryantalist Maurice Gaudefroy-Demombynes (ö.1957), Goldziher'in görüşlerine bazı noktalarda karşı çıkacaktır. Gaudefroy-Demombynes'e göre, İslam öncesindeki büyüsel lanetlemelerle hiciv sanatının özdeş olduğunu iddia etmek mümkün değildir. Bu savını açıklamak için, Bedir Savaşında Hz. Muhammed'in bir avuç kumu savurarak Kureyşli düşmanlarına ettiği bedduayı örnek olarak seçmektedir. Kumun savurulmasının ve lanetleme ifadesinin telaffuz edilmesinin ardından, düşmana karşı savaşacak bir tabur meleğin yardıma gelmesiyle sonuçlanan bu ilenme örneği ile hiciv sanatının aynı karaktere sahip olmadığı, bu bağlamda öne sürülmektedir. Elbette Gaudefroy-Demombynes bu fikri ortaya atarken Hz. Peygamberin gerçekleştirdiği bu eylemin, İslam öncesindeki büyüsel ritüellerin yeni dine uyarlanmasından ibaret olduğu iddiasındadır (Ibn Qotaiba, 1947, s.XVIII). Ancak Hz. Peygamberin burada bir avuç kumdan istifade etmesi, sihirbazların karşısında asâsından yararlanarak büyüsel güçlerin üstüne çıkmayı başaran $\mathrm{Hz}$. Musa’nın mucizesiyle özdeşleştirilmelidir. Nitekim İbranîlerin peygamberlik geleneklerinde de bazı ilahî mucizelerin, belirli materyallerin veya belirli seslerin kullanılmasıyla gerçekleştirildiği bilinmektedir. Örneğin; İbranilerin dinsel metinlerine göre, savaşlarda şofar üflenmesiyle, sağlam duvarlar mucizevi şekilde ylkılabilmektedir (Friedmann, 2013, s.74).

İslam kaynaklarında, Hz. Peygamberin bu eylemi ilahî bir mucize olarak değerlendirilmektedir. Rivayetlere göre, Hz. Muhammed, Allah’a hizmet etmek isteyenlerin Bedir'de toplanması yönünde çağrıda bulunmuştur. Yaklaşık üç yüz kişiden oluşan bu Müslüman birliğinin yanında, yalnızca iki at ve yetmiş deve bulunmaktadır. Oysa müşrikler, bin kişi toplamayı başarmıştır. Hal böyle olunca, Hz. Cebrail, Hz. Muhammed'in yanına gelmiş ve yerden bir avuç toprak alarak düşmana doğru savurmasını söylemiştir. Hz. Muhammed, yerden aldığg bir avuç ince çakılı müşriklere doğru üfürmeden önce, şu ilenme sözcüklerini söylemiştir: "شَاهَتْ الُْوجُوهُ " “Yüzler çirkinleşsin!” Bu lanetlemenin ardından, Hz. Peygamber sayıca çok üstün olan düşman kuvvetlerinin yenileceğini müjdelemiştir (İbn 'Âşûr, 1984, c.9, s.294; Booth, 2014, s.212; Balc1, 2009, s.106). Hz. Muhammed, söz konusu eylemi Ḥuneyn Gazvesinde tekrarlayacaktır. Aynı beddua sözcüklerinin telaffuz edilmesinin ardından, hem gözleri hem de ağızları toprakla dolan müşriklerin hezimete uğradığı aktarılmaktadır (edDârimî, 1421/2000, c.1, s.1593). Bu mucizevi lanetlemelerin akabinde, aşağıdaki ayetinin indiği kaydedilmektedir:

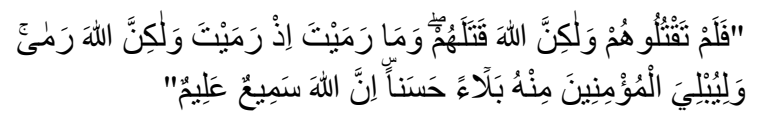

"Onları siz öldürmediniz; ama onlarn Allah öldürdü. Attığın zaman da sen atmadın; ama Allah attı. Bunu, Müminleri güzel bir imtihanla denemek için (yaptı). Allah işitendir, bilendir (Kur’an-1 Kerim, 2018, Enfâl 8/17).”

Daha ziyade hicvin maddi yönü üzerinde duran Gaudefroy-Demombynes’e göre, yergiciler, beyitlerindeki ritmik formüller vasıtasıyla, düşmanlarının üzerinde bırakacakları olumsuz etkilerin farkındadır. Hicviyelerinde karşı tarafa hem kendilerinin hem de kabilelerinin kinini aktaran şairler, hedef aldıkları kişileri sonsuza dek damgalayabileceklerini (vesm) çok iyi bilmektedir (Ibn Qotaiba, 1947, s.XVIII). Şairlerin yerginin maddi gücünün farkında olmadığını iddia etmek, elbette mümkün değildir. Ancak bu farkındalık, hicivciliğin eskiden büyücülükle bağdaşık olduğu gerçeğini değiştirmemektedir. Çünkü kâhinler de icra ettikleri mesleğin safsatadan ibaret olduğunu bilmektedir. Buna rağmen kâhinler, halkın ruh sağlı̆̆ını bozmak pahasına, tarihin hiçbir safhasında dolandırıcılıklarından geri durmamışlardır. Dolayısıyla bazı yergicilerin, bilinçli şekilde kâhinlerin hilekârlıklarını sürdürmeyi seçmiş olması, hiç de şaşırtıcı değildir. Söz konusu hilekâr yergicilerin, hiciv söylerken uyguladıkları gösterilere tevessül etmeyen profesyonel şairlerin sayısı, zamanla çoğalmış 
olmalıdır. Yalnızca bu arızi profesyonelleşmeye bakılarak hicvin geçmişte büyücülükle ilişkili olarak icra edildiğini gösteren tüm delillerin yok sayılması, son derece yanlış olacaktır.

Edouard (Bichr) Farès (ö. 1963), hicve atfedilen büyüsel karakteri tartışmaya açan önemli araştırmacılardan bir diğeridir. Farès'e göre, Goldziher'in görüşleri tek ve mutlak bir kanıta dayanmaktan ziyade, birbirini destekleyen ayrıntılara ve diğer edebiyatlarla yapılan mukayeseler neticesinde varılan çıkarım ve değerlendirmelere dayanmaktadır. Goldziher'in metoduna, yani Emevî Dönemi secilerinden alınan bedduaların hicvin gerçek yapısının tespitinde delil olarak kullanılmasına, Farès tarafından karşı çıkılmaktadır (Farès, 1932, s.214-218; van Gelder, 1989, s.4). Gerçekten de hicvin ilkel formlarının anlaşılması açısından, geç dönem secilerinin sağlam bir delil niteliği arz etmeyeceği aşikârdır. Ancak İslam öncesine ait bazı yergisel kâhin secilerinin bulunduğu da bu bağlamda göz ardı edilmemelidir (İbnu'l-Esîr, 1407/1987, c.1, s.554). Hicvin büyüsel kökenine karşı çıkanlar açısından, $s e c$ 've karîd türlerinin, yapı, üslup ve içerik açısından birbirinden ayrılıyor olması, diğer bir problemdir. Van Gelder'ın aktardığı üzere, lanetlemeler, tipik olarak tek bir biçimsellikte söylenen belirli formüllerden müteşekkildir. Genellikle kapalılığın kullanıldığı büyü sözlerinde, arkaik ifadelere yer verilmektedir. Hicivse daha esnek, daha basit ve daha direkt bir yapıya sahiptir. Ayrıca yergilerde tanrılara değil, insanlara hitap edilmektedir. Bunun yanı sıra, hicviyelerde insanların haysiyetlerini zedeleyecek hakaretlerin kullanılması, bu ritmik hiciv dizelerini büyü sözlerinden ayıran unsurlar arasında sayılmaktadır. Ancak Farès, insanların mahvını amaçlayan hiciv ile büyü kavramlarının, nihai olarak tek bir amaç doğrultusunda birleştiğini kabul etmektedir (van Gelder, 1989, s.4).

Takdir edileceği üzere, hiciv sanatının kendi özünde barındırdığı kuvvet, büyüye hiç gerek kalmadan da son derece etkilidir. Lakin hiciv sanatının, en azından bir dönem boyunca, düşmanın fiziksel olarak zayıflatılmasını veya tamamen ortadan kaldırılmasını hedefleyen bazı doğaüstü uygulamalarla ilişkilendirildiği de yadsımayacak bir gerçektir. Hz. Muhammed'in hicivciliğe çok temkinli yaklaşmış olması bile, bu sanatın bir zamanlar büyücülükle ilişkilendirildiğinin göstergelerindendir. Fransız müsteşrik Charles Pellat (ö. 1992)'ya göre, hoşgörüyü ve müsamahakârlı̆̆ı tavsiye eden Hz. Peygamberin, kendisini hicvedenlere lanet etmiş olması, onun yergileri uğursuzlukla ilişkilendirdiğini göstermektedir (Pellat, 1986, s.353). Hz. Peygamberin Müslümanlarla İslam aleyhtarları arasındaki hicivleşme yarışıyla bizzat alakadar olduğu göz önüne alındığında, dönemin Araplarının hicve ne denli ulvi bir anlam yüklediği açıkça görülmektedir. Muhtemelen bu durum, Sâmî kültürlerinde "sözün” çok kutsal olduğuna inanılmasından kaynaklanmaktadır. Hicviyeler "sözlü" hakaret olduğu için, bu şiirlerin uğursuzluk getirebileceğine inanılmış olması, hiç de şaşırtıcı değildir. Dolayısıyla eski Araplarının hicvedilmekten bu kadar korkması, İbrahimî dinlerin söze atfettiği kutsiyetin bir yansıması olarak değerlendirilebilir (bkz. The Holy Bible, 2011, John, 1:1, s.507).

\section{Sonuç}

Hiciv teması, klasik Arap şiirinin en temel ve en yaygın konularından birisidir. İslam öncesinde ve Sadru'lİslam Döneminde, Arap hicvinin en seçkin örneklerinin ortaya konduğu ve hicivciliğin altın çağını yaşadığ 1 bilinmektedir. Bu öncü çalışmalar, ilerleyen asırların yergicilik geleneklerini derinden etkileyecektir. Klasik Arap hicvi, mertlik yahut muruvve kavramıyla doğrudan doğruya ilişkilidir. Erken döneme ait hemen hemen tüm kasideler, bir şekilde hedef alınan kişi veya kabilelerin mertlik erdeminden soyutlanarak küçük düşürülmesini amaçlamaktadır. Yerleşik devlet düzeni topluma hâkim olmadığından, İslam öncesinde sık sık çatışmalar yaşanmaktadır. Sonu gelmez savaşların, hicvin yaygınlık kazanmasında ve şekillenmesinde önemli bir rol oynadığı açıktır. Bilindiği üzere, klasik dönem boyunca söylenegelen hicviyelerde, son derece klişeleşmiş yapılar baskınlık kazanmış durumdadır. Bu basmakalıp ifadelerin asıl nedeni, hicivciliğin askerî faaliyetlerde kullanılan bir tür iletişim aracına dönüştürülmüş olmasıdır. Dolayısıyla bir kabilenin hiciv sanatına hâkim olan şairler yetiştirebilmiş olması, güçlü bir propaganda yapabilmesi için en gerekli unsurdur. 
Hiciv (hicâ') sözcüğ̈̈, pek çok Sâmî dilinde karşımıza çıkmakta ve yergiciliğin Ortadoğu halkları arasında çok eskilere uzanan bir geleneğe dayandığını anlamamıza olanak sağlamaktadır. Mısır, Sümer, Babil gibi kadim medeniyetlerin kayıtlarında, erken dönem Arap hicvinin örneklerini çağrıştıran yergisel ürünlere rastlamak mümkündür. Bilinmeyen bir tarihte, bölge halkları arasında, belirli bir ölçüye kadar kültürel aktarım sağlandığı açıktır. Arap coğrafyasında yerleşik olan ve kadim dünyanın entelektüel geleneklerinin hamiliğini üstlenen Yahudi toplumunun, Arap yergisinin doğuşunda ve gelişmesinde, doğrudan veya dolaylı olarak önemli katkılarda bulunduğu gözlemlenmektedir. Nitekim Arapların Yahudilerden kâhinlik ve büyücülük sanatını öğrenmesiyle birlikte, Arap yergisi bu ezoterik geleneklerin tesiriyle ilk önemli atılımını gerçekleştirebilecektir. Kâhinlerin yergisel secileri (escâ'), muhtemelen Arap şiirinin en eski örneklerini meydana getirmektedir. Bu ritmik tekrarlamalar, zamanla yergisel recezlere dönüştürülerek klasik kaside halini almış olmalıdır. Farklı konuları ihtiva eden klasik kasidelerin içerisinde, tematik bir kısım olarak yer alan hicviyeler, yergi sanatının Arap edebiyatında ulaşabildiği en seçkin ve en sanatsal düzeyi temsil etmektedir.

Arap hicvinin ortaya çıkmasında, her şeyden önce toplumun ve insanların psikolojisinin etkili olduğu görülmektedir. Kitle psikolojisi veya kabilecilik bilinci, erken dönem şairlerini yergi söylemeye iten en temel etkendir. Öyle ki İslam öncesinde veya Sadru'l-İslam Döneminde, kabilecilik taassubuyla öyle veya böyle alakalı olmayan bir hicviyeye rastlamak, neredeyse imkânsıza yakındır. Şairler anlık duygulanımlarını, kin ve öfkelerini, en iyi şekilde hiciv söyleyerek ifade edebilmektedir. Dolayısıyla eski Arapların sert mizacının hicve olan etkisi muazzamdır. Erken dönem Arap hicvinin, çoğu zaman aşılması güç bir ciddiyet perdesinin ardında kalmış olması da bu yüzdendir. Dinî inanışların veya daha doğru bir ifadeyle topluma hâkim olan büyüsel kültlerin, hicivciliğin insanlar üzerindeki etkisini büyük ölçüde arttırdığı görülmektedir. Çünkü yergicilerin cinlerle veya kötü ruhlu şeytanlarla iletişim kurduğu varsayımı, eski Arapların hicvedilmekten ölesiye korkmasına neden olmaktadır.

Klasik Arap hicvinin büyük ölçüde özgün bir gelişim gösterdiği söylenebilir. Öte yandan yergiciliğe dair ilk fikir nüvelerinin yahut büyüselliğe dayalı secili lanetleme geleneklerinin, kadim medeniyetlerden esinlenmiş olması da muhtemeldir. Hakikat her ne olursa olsun, Arap yergicileri tarafindan bu fikirlerin Bedevî ruhuna uygun olarak özgün bir biçimde yorumlanabildiği gözlemlenmektedir. Hatta Arap yergisinin, Ortadoğu'nun en özgün ve en kapsamlı yergicilik geleneği olduğunu söylemek abartılı olmayacaktır. 


\section{Kaynakça}

el-A'şâ,, M. (t.y.). Dîvânu'l-A 'şâ el-Kebîr. M. Huseyn (haz.). el-Cemâmîz: Mektebetu'l-Adâb.

Apak, A. (2015). İslam öncesi Arapların ulûhiyet anlayışında kâhinlerin yeri. M. M. Söylemez (ed.). Cahiliye Araplarının ulûhiyet anlayışı (53-77) içinde. Ankara: Ankara Okulu.

Atto, S. (1990). Süryanice-Türkçe sözlük (2. Baskı). Hollanda: Simon Atto.

Balcı, İ. (2009). Bedir savaşıyla ilgili mucizevi rivayetlerin Kur'ân, Hadis ve tarih verilerine göre kritiği. İSTEM, 13, 85-124. Erişim adresi: https://dergipark.org.tr/tr/pub/istem/issue/26540/279426

Ball, C. J. (1913). Chinese and Sumerian. Londra: Oxford University Press.

Bensew, J. L. (1862). Ozar haschoroschim, hebräisch-deutsches und deutsch-hebräisches Wörterbuch über das Alte Testament (4. Baskı, Cilt 1). Viyana: Verlag von J. Knöpflmacher und Söhne.

Booth, M. (2014). The sacred history: How angels, mystics and higher intelligence made our world. New York: Atria Books.

Bryces, T. (2014). Ancient Syria: A three thousand year history. Oxford: Oxford University Press.

ed-Dârimî, Ebû M. A. b. A. (1421/2000). Musnedu'd-Dârimî (Cilt 1). H. S. U. ed-Dârânî (thk.). Riyad: Dâru'lMug̉nî li’n-Neşr ve’t-Tevzî‘.

Ḍayf, Ş. (t.y.). Târîhu'l-edebi'l-'Arabî; el-'Așru'l-Câhilî (22. Baskı, Cilt 1). Kâhire: Dâru'l-Me'ârif.

ed-Dehhân, S. (t.y.). el-Hicâ' (3. Baskı). Kâhire: Dâru’l-Me ârif.

Farès, B. (1932). L'Honneur chez les Arabes avant l'Islam. Paris: Librairie d'Amérique et d'Orient Adrien Maisonneuve.

Figueroa, M. R. (1975). Mercaderes, dioses y beduinos: El sistema de autoridad en Arabia preislámica. Meksika: Colegio de México.

el-Fîrûzâbâdî, M. (2005). el-Kâmûsu'l-muhîț (8. Baskı). Mektebu Taḥkîkịit-Turâs_fî Muesseseti’r-Risâle (thk.). Beyrût: Muessesetu'r-Risâle.

Friedmann, J. L. (2013). Music in biblical life: The roles of song in ancient Israel. Kuzey Carolina-Londra: McFarland \& Company.

van Gelder, G. J. H. (1989). The bad and the ugly: Attitudes towards invective poetry (hijä') in classical Arabic literature. Leiden-New York-Kopenhag-Köln: E. J. Brill.

Geyer, R. (1892). Gedichte und Fragmente des 'Aus ibn Hajar. Viyana: In Commission bei F. Tempsky.

Goldziher, I. (1891). Die Ǵinnen der Dichter. Zeitschrift der Deutschen Morgenländischen Gesellschaft, 45(4), 685-690. Erişim adresi: https://www.jstor.org/stable/43362203

Goldziher, I. (1896). Abhandlungen zur arabischen Philologie (Cilt 1). Leiden: E. J. Brill.

Huart, C. (1903). A history of Arabic literature. New York: D. Appleton and Company.

Huseyn, M. M. (t.y.). el-Hicâ' ve'l-heccâ'ûn fîl-Câhiliyye. el-Cemâmîz: Mektebetu'l-Âdâb. 
Ibn Qotaiba. (1947). Introduction au Livre de la Poésie et des Poètes. M. Gaudefroy-Demombynes (haz.), Paris: Les Belles Lettres.

İbn 'Abdi'l-Berr, Ebû Ö. (1412/1992). el-İstî̀âb fî ma'rifeti’l-Așhâab (Cilt 3). A. M. el-Becâvî (thk.). Beyrut: Dâru’l-Cîl.

İbn ‘Âşûr, M. eț-Ṭ. (1984). Tefsîru’t-tahrîr ve’t-tenvîr (Cilt 9). Tunus: Dâru’t-Tûnisiyye li’n-Neşr.

İbn Hişâm (1375/1955). es-Sîretu'n-Nebevîyye (2. Baskı, Cilt 2). M. es-Saḳkâ, İ. el-Ebyârî, 'A. eş-Şelebî (haz.). Mısır: Mustafa el-Bâbî el-Ḥalebî ve Evlâduhu.

İbn Manẓ̂̂r, Ebû̉l-F. (t.y.). Lisânu'l-'Arab (Cilt 15). Beyrut: Dâr Șâdır.

İbnu'l-Eșîr, Ebû'l-Ḥ. (1407/1987). el-Kâmil fîtt-târîh (Cilt 1). Ebû’l-F. 'A. el-Kâdûi (thk.). Beyrut: Dâru'lKutubi'l-'İlmiyye.

İbn Zâkûr, Ebû 'Abdi'l-lah Muhammed b. Kasım el-Fâsî (2013). 'Unvânu'n-Nefâse fî Şerhi'l-Hamâse (Cilt 1). M. Cemâlî (thk.). Beyrut: Dâru’l-Kutubi'l-'İlmiyye.

Jacob, G. (1897). Altarabisches Beduinenleben: Nach den Quellen geschildert. Berlin: Mayer \& Müller.

el-Ḳayrevânî, İbn R. (1401/1981). el-'Umde: Fî mehâasini’şş̧ír ve âdâbihi ve naḳdihi (5. Baskı, Cilt 1). M. M. Abdülhamid (haz.). Beyrut: Dâru'l-Cîl.

König, E. (1910). Hebräisches und aramäisches Wörterbuch zum Alten Testament. Leipzig: Dieterich'sche Verlagsbuchhandlung.

Kramer, S. N. (1949). Schooldays: A Sumerian composition relating to the education of a scribe. Journal of the American Oriental Society, 69(4), 199-215. doi: 10.2307/596246

Kramer, S. N. (2002). Tarih Sümer'de başlar (2. Baskı). H. Koyukan (çev.). İstanbul: Kabalcı.

Kur’an-ı Kerim (2018). (5. Baskı). İstanbul: Diyanet İşleri Başkanlığı.

Mevsû'atu'ş-Şurûk (1994). (Cilt 1). Kâhire: Dâru'ş-Şurûḳ.

Montgomery, J. E. (1986). Dichotomy in jâhilî poetry. Journal of Arabic Literature, 17, 1-20. Erişim adresi: https://www.jstor.org/stable/4183129

Nork, Fr. (1842). Vollständiges Hebräisch-chaldäish-rabbinisches Wörterbuch über das Alte Testament. Grimma: Verlags-Comptoirs.

Pellat, C. (1986). Hidjâ'. The encyclopaedia of Islam (Cilt 3). Leiden: E. J. Brill.

er-Râzî, M. (1401/1981). Tefsîru'l-Fahri'r-Râzî (Cilt 2). Beyrut: Dâru'l-Fikr.

Rollston, C. A. (2001). Ben Sira 38:24-39:11 and the "Egyptian satire of the trades": A reconsideration. Journal of Biblical Literature, 120(1), 131-139. doi:10.2307/3268597

Russell, B. \& Russell, D. (1959). The Prospects of Industrial Civilization (2. Bask1). Londra-New York: Routledge.

Simpson, W. K. (2003). The literature of ancient Egypt: An anthology of stories, instructions, and poetry (3. Baskı). R. K. Ritner, W. K. Simpson vd. (çev.). New Haven-Londra: Yale University Press. 
Smith, R. P. (1998). A compendious Syriac dictionary. J. P. Smith (ed.). Indiana: Eisenbrauns.

Stordalen, T. (2013). Ancient Hebrew meditative recitation. H. Eifring (ed.). Meditation in Judaism, Christianity and Islam: Cultural histories (17-32) içinde. Londra-Yeni Delhi: Bloomsbury.

Şemseddin, İ. (1423/2002). Kıı̣̦ạ̦u'l-'Arab: Mevsû'a turâsiyye câmi'a (Cilt 4). Beyrut: Dâru'l-Kutubi'l-'İlmiyye.

The Holy Bible: King James version. (2011). ABD: Hendrickson Publishers.

et-Tuncî, M. (1419/1999). el-Mu'cemu'l-mufașșal fîl'-edeb (2. Baskı, Cilt 2). Beyrut: Dâru'l-Kutubi'l-‘ìlmiyye.

van Vloten, G. (1893). Dämonen, Geister und Zauber bei den alten Arabern. Mittheilungen aus Djâhitz' Kitâb al-haiwân. Wiener Zeitschrift für die Kunde des Morgenlandes, 7, 169-187. Erişim adresi: https://www.jstor.org/stable/23860807

Wehr, H. (1985). Arabisches Wörterbuch für die Schriftsprache der Gegenwart (5. Bask1), Wiesbaden: Harrassowitz Verlag.

Willmet, I. (1784). Lexicon Linguae Arabicae: In Coranum, Haririum et Vitam Timuri. Rotterodami: C. R. Hake.

Wilson, J. A. (1992). Ancient Near Eastern texts: Relating to the Old Testament (5. Baskı). J. B. Pritchard (ed.). Princeton-New Jersey: Princeton University Press.

Yakup b. İshak, Ebû 'A. (1419/1998). Musnedu Ebî 'Avâne (Cilt 5). E. b. 'Â. ed-Dimaşḳ̂i (thk.). Beyrut: Dâru’lMa'rife.

Zuheyr b. Ebî Sulmâ (1426/2005). Şerhu Dîvâni Zuheyr b. Ebî Sulmâ (2. Baskı). Ḥ. Ṭammâs (haz.). Beyrut: Dâru'l-Ma'rife. 